\title{
Prevalence and Genetic Diversity of Aichi Virus 1 from Urban Wastewater in Senegal
}

\author{
Ousmane Kebe ${ }^{a}$ Maria-Dolores Fernandez-Garcia ${ }^{a}$ Amary Falla Hamet Dia ${ }^{a}$ \\ Maxime Bidalot $^{b} \quad$ Katia Ambert-Balay $^{b}$ Kader Ndiaye ${ }^{a}$ \\ aLaboratory of Enteric Viruses, Virology Unit, Institut Pasteur, Dakar, Senegal; b National Reference Centre for \\ Gastroenteritis Viruses, Laboratory of Biology and Pathology, University Hospital Dijon, Bourgogne, Dijon, France
}

\section{Keywords}

Aichi virus 1 . Senegal - Sewage - Wastewater treatment

plant $\cdot$ Molecular epidemiology

\begin{abstract}
Aichi virus 1 (AiV-1) has been proposed as a causative agent of human gastroenteritis. In this study, raw, decanted, and treated wastewater samples from a wastewater treatment plant in an urban area of Dakar, Senegal, were collected. AiV1 was detected in raw $(70 \%, 14 / 20)$, decanted $(68.4 \%, 13 / 19)$, and treated $(59.3 \%, 16 / 27)$ samples, revealing a noticeable resistance of AiV-1 to chlorine-based treatment. Phylogenetic analysis revealed that all sequences clustered within genotype B. Our study presents the first report on the detection of AiV-1 in the environment of Dakar and constitutes indirect evidence of virus circulation in the population.
\end{abstract}

(c) 2021 S. Karger AG, Basel

\section{Introduction}

Aichi virus 1 (AiV-1) is a human enteric virus of the genus Kobuvirus within the Picornaviridae family. It is a small, non-enveloped, positive-sense, single-stranded
RNA virus of approximately $8.3 \mathrm{~kb}$ in length [1]. AiV - 1 is classified into 3 genotypes ( $\mathrm{A}, \mathrm{B}$, and $\mathrm{C}$ ) using the conserved nucleotide sequences of the $3 \mathrm{C}$ and $3 \mathrm{D}$ (3CD) junction region of the genome [2,3]. It has been proposed as a causative agent of human gastroenteritis potentially transmitted primarily by the fecal-oral route [1]. AiV-1 shedding in human feces may contaminate aquatic environments directly or after discharge of raw or treated sewage [4-7]. AiV-1 is known to be resistant to different treatment procedures, and once in the environment, it can persist for a very long time $[4,8]$. The presence of AiV-1 in aquatic environments has been reported in previous studies that detected $\mathrm{AiV}-1$ in river water $[5,7,9]$, in sewage [6,9-14], in sewage sludge [15], in groundwater $[9,16]$, and shellfish $[10,13,17-19]$. AiV-1 detection in humans was initially reported as the likely cause of an oyster-associated gastroenteritis outbreak in Aichi, Japan, in 1989 [20]. Since then, the virus has been found at low incidence in patients with gastroenteritis in different regions of the world, including Asian [2, 21-24], European [3, 25-29], South American [25], and African [30, $31]$ countries. The seroprevalence of $\mathrm{AiV}-1$ reaches 80 $95 \%$ by the age of $30-40$ years $[1,32,33]$. The incongruity between low detection rates in gastroenteritis cases and high seroprevalence suggests that the virus might be karger@karger.com

www.karger.com/int

Karger
(C) 2021 S. Karger AG, Basel

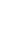

\footnotetext{
Maria-Dolores Fernandez-Garcia

Laboratory of Enteric Viruses, Virology Unit

Institut Pasteur de Dakar, 36 Bd Pasteur

Dakar BP 220 (Senegal)

dolores.fernandez@yahoo.es
} 
responsible for asymptomatic or mild infections [1]. Wastewater surveillance is a useful tool to understand the prevalence and circulation of enteric viruses within a human population as wastewater contains viruses shed from all individuals within a service area regardless of symptoms [34]. In this regard, examining environmental samples is especially useful for viruses such as $\mathrm{AiV}-1$ that are underdiagnosed and potentially hazardous to health [35]. In Africa, AiV-1 has been detected in sewage samples in Tunisia and South Africa [10, 12, 13], in gastroenteritis cases in Tunisia and Burkina Faso [30,31], and from fecal samples of healthy children in Ethiopia [36]. To date, there are no documented reports on the molecular epidemiology of AiV-1 in Senegal. For this aim, we investigated the occurrence and genetic diversity of AiV-1 in raw and treated sewage samples from a WWTP located in a major urban area of Dakar.

\section{Materials and Methods}

Samples of this study were collected at the WWTP of Cambérène, Dakar, Senegal (Fig. 1). The WWTP process for wastewater consists of (1) screening fat, oil grease, and sand removal (raw sewage); (2) decantation (decanted sewage); and (3) chlorination (treated sewage) (level of chlorine dose $10 \mathrm{~g} / \mathrm{L}$, chlorine residual $0.5 \mathrm{mg} / \mathrm{L}$ ). A total of 66 wastewater samples (20 raw, 19 decanted, and 27 treated) were collected once per week from November 2012 to March 2013 in the morning between $9.00 \mathrm{a} . \mathrm{m}$. and $11.00 \mathrm{a} . \mathrm{m}$. using the grab method as described in the WHO Guidelines for Environmental Surveillance of Poliovirus [37]. The concentration of wastewater samples was performed using the two-phase separa- tion method using polyethylene glycol 6000 and dextran 40 as previously described [37, 38]. RNA was extracted from $140 \mu \mathrm{L}$ of the concentrated virus solution using a commercial QIAamp Viral RNA Kit (Qiagen Inc., Germany) according to the manufacturer's instructions. The presence of AiV-1 RNA was assessed using the primer set Ai6261 and Ai6779 specific for AiV-1, targeting a 519base pair fragment at the $3 \mathrm{CD}$ junction [2]. RT and PCR were performed in a 1-step procedure, using the QIAGEN ${ }^{\circledR}$ One-Step RTPCR Kit. Amplified PCR fragments were purified using the GeneJET Gel Extraction (Thermo Fisher Scientific) according to the manufacturer's instructions. Genotyping was performed by direct sequencing of amplified products by the Sanger method using Ai6261 and Ai6779 primers. Nucleotide sequences were deposited in the GenBank database (MK213084 to MK213109). All sequences were aligned by using ClustalW multiple alignment program within the BioEdit Sequence Alignment Editor package, version 7.0.9.0. Phylogenetic studies and genetic distances were calculated by using the Molecular Evolutionary Genetics Analysis 6 (MEGA6) software.

\section{Results and Discussion}

Out of 66 wastewater samples, 43 (65.1\%) were found to be positive for AiV-1 RNA. AiV-1 was detected in $14 / 20$ (70\%) raw, 13/19 (68.4\%) decanted, and 16/27 (59.3\%) treated wastewater samples, demonstrating high and constantly abundant $\mathrm{AiV}-1$ detection rates in influent and effluent wastewater. The significant percentage (59.3\%) of AiV-1 prevalence in effluent wastewater highlights the difficulty in eliminating $\mathrm{AiV}-1$ by the current treatment methods of chlorination. This result is in agreement with the established environmental stability of AiV-

Fig. 1. Geographical location of the study

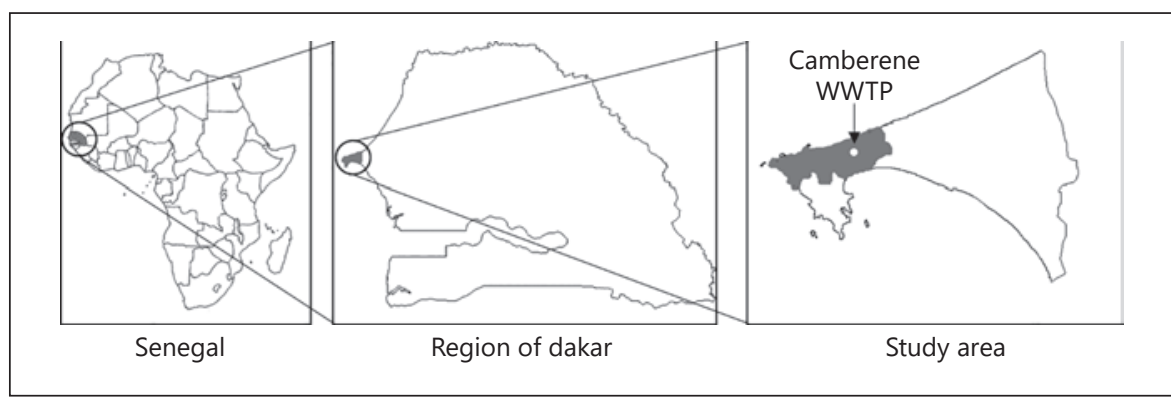
area.

Fig. 2. Phylogenetic analysis of AiV-1 strains recovered from a WWTP in an urban area in Dakar and a representative global set of AiV-1 strains from the GenBank database, based on a 301-base pair fragment of the genomic $3 \mathrm{CD}$ junction region. The tree was inferred with a neighbor-joining method. Distances were computed using the Kimura 2-parameter model in the package MEGA6. The robustness of the nodes was tested by 1,000 bootstrap replica- tions. Bootstrap support values $>75 \%$ are shown in nodes. Black triangles indicate the 26 strains from this study. Scale bar represents nucleotide substitutions per site. A value of 0.05 substitutions per site is equivalent to $5 \%$ changes. Abbreviations of virus names indicate GenBank accession number, strain name, source, year of collection, and country of origin. AiV-1, Aichi virus 1 .

(For figure see next page.) 


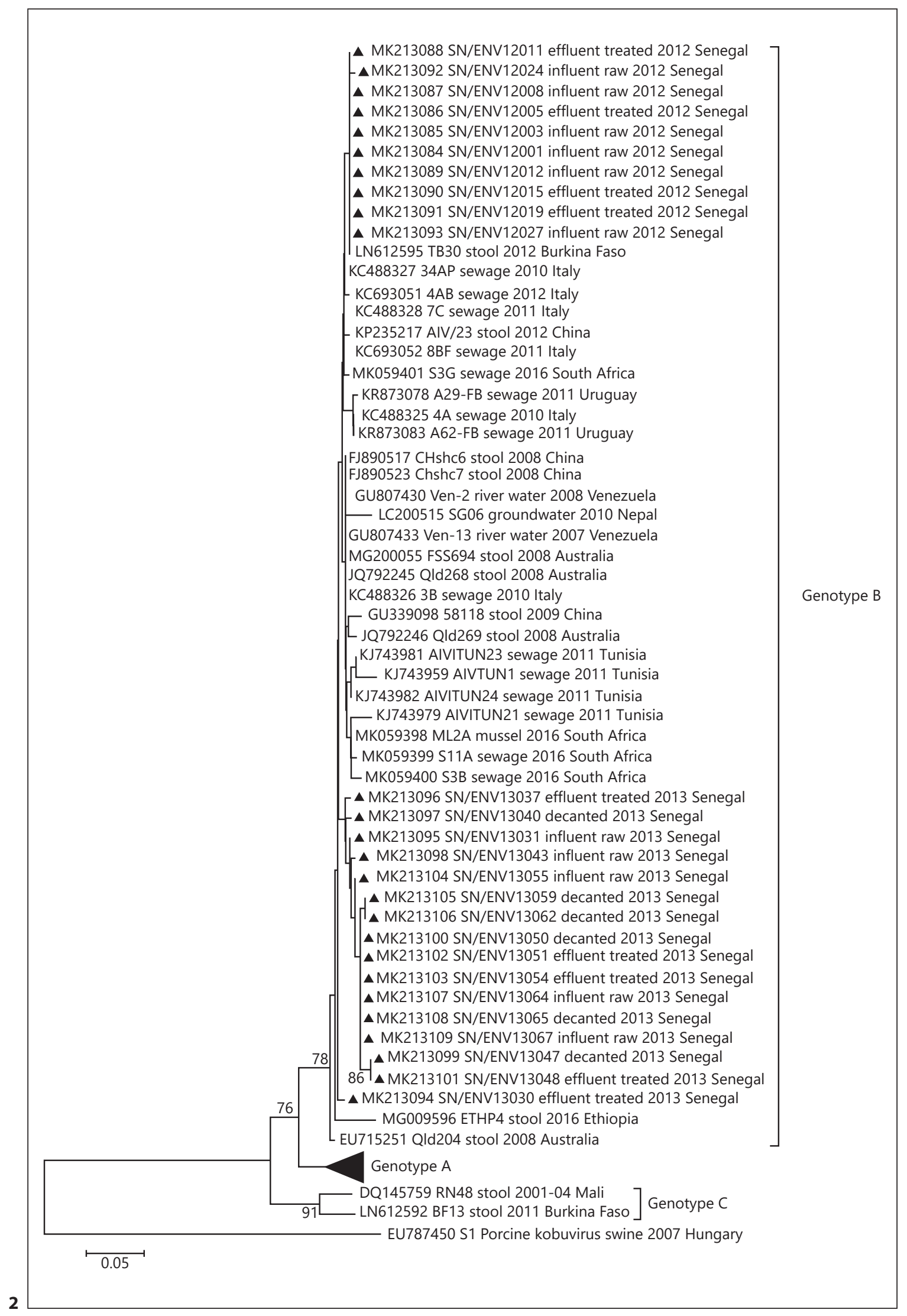


1 and its known low-pH resistance [8]. The study supports others in providing further evidence of the high persistence of AiV-1 during similar wastewater treatments $[5,12,35,39,40]$. The observation of a high detection rate in the dry cold season (season of this study) is in accordance with results reported in previous studies in Africa $[12,31]$. This can be explained by the influence of temperature on the persistence of enteric viruses in aquatic environments [12]. Indeed, viral inactivation of enteric viruses is faster when the water temperature is very high. In particular, for $\mathrm{AiV}-1$, inactivation has been reported to occur at $56^{\circ} \mathrm{C}$ for $20 \mathrm{~min}$ by heat treatment [8].

A total of 28 out of $43 \mathrm{AiV}$-1-positive samples were used for genotyping. Majority $(26 / 28,92.8 \%)$ were successfully genotyped. Sequence and phylogenetic analysis of the 3CD nucleotide sequences of the 26 strains indicated that all strains belonged to genotype B (Fig. 2). This is in agreement with previous studies in the African region (Ethiopia, South Africa, Burkina Faso, and Tunisia) reporting the predominance of genotype B in clinical and wastewater samples $[12,13,30,36]$. Nevertheless, genotype A has also been reported in Africa in clinical and wastewater samples $[3,10,30]$. Interestingly, the only 3 AiV-1 strains from genotype $\mathrm{C}$ published in GenBank are from Africa (Mali and Burkina Faso) [3, 30]. However, genotype $\mathrm{C}$ has never been isolated from wastewater. A notable observation was segregation of study sequences in 2 clusters that occurred sequentially in time: strains from 2012 grouped in 1 cluster different from those of 2013 (Fig. 2). However, the low mean $p$-distance between both clades $(0.008 \mathrm{SE} \pm 0.003)$ and the low bootstrap values (63\% for the 2012 cluster and 33\% for the 2013 cluster, data not shown) suggest low genetic divergence among them. Despite the low degree of variability, this evident temporal shift of $\mathrm{AiV}-1$ strains in a restricted geographical region agrees with what has been observed in other studies $[10,41]$. The $10 \mathrm{AiV}-1$ strains of the 2012 cluster showed 99\% nucleotide sequence identity (mean $p$-distance of $0.002 \mathrm{SE} \pm 0.001)$ to an AiV-1 strain (LN612595) detected in a stool specimen from a child with gastroenteritis in Burkina Faso in 2012, which clustered in the same monophyletic group (Fig. 2). This high similarity among the AiV-1 strain detected in a human clinical case and the $\mathrm{AiV}-1$ strains detected in sewage suggests a direct link between contaminated water and human infection with $\mathrm{AiV}-1$. Senegalese strains were found to be genetically related (90-99\% of nucleotide identity) to AiV-1 strains detected in different geographical areas such as China [22], Italy [11], Venezuela [7], or Tunisia [12], evidencing the circulation of closely related strains worldwide.

\section{Conclusion}

This study describes for the first time the occurrence and genetic diversity of this virus in the environment of Senegal. Results reported here revealed a high frequency of AiV-1 in effluent wastewater, suggesting that chlorinebased sewage treatment is only partially effective for the removal of viruses. In the WWTP of Cambérène, the effluent wastewater is partly drained to the ocean and partly used for irrigating agricultural areas that provide vegetables in several markets of Dakar [42]. Discharge of the virus into the marine environment or the use of contaminated effluent wastewater for irrigation may represent a risk on human health and ecology of aquatic environments. Further studies are warranted in order to assess the potential role of $\mathrm{AiV}-1$ discharge in the natural environment as a causative agent of gastroenteritis in Senegal.

\section{Acknowledgements}

Our thanks to the management of the National Office of Sanitation (ONAS) of Senegal and its staff for facilitating this work by welcoming us on the site.

\section{Statement of Ethics}

This article does not contain any studies with human participants or animals.

\section{Conflict of Interest Statement}

The authors declare that there are no conflicts of interest.

\section{Funding Sources}

This work received no specific grant from any funding agency in the public, commercial, or not-for-profit sectors.

\section{Author Contributions}

Kader Ndiaye and Ousmane Kebe conceived the study. Amary Fall, Hamet Dia, and Maxime Bidalot performed research. Ousmane Kebe and Maria-Dolores Fernandez-Garcia analyzed the data. Ousmane Kebe, Maria-Dolores Fernandez-Garcia, Amary Fall, Katia Ambert-Balay, and Kader Ndiaye interpreted the data. Ousmane Kebe and Maria-Dolores Fernandez-Garcia wrote the manuscript. All authors reviewed and approved the manuscript. 


\section{References}

1 Reuter G, Boros A, Pankovics P. Kobuviruses: a comprehensive review. Rev Med Virol. 2011;21(1):32-41.

2 Yamashita T, Sugiyama M, Tsuzuki H, Sakae K, Suzuki Y, Miyazaki Y. Application of a reverse transcription-PCR for identification and differentiation of Aichi virus, a new member of the Picornavirus family associated with gastroenteritis in humans. J Clin Microbiol. 2000;38(8):2955-61.

3 Ambert-Balay K, Lorrot M, Bon F, Giraudon H, Kaplon J, Wolfer M, et al. Prevalence and genetic diversity of Aichi virus strains in stool samples from community and hospitalized patients. J Clin Microbiol. 2008; 46(4):1252-8.

4 Kitajima M, Gerba CP. Aichi virus 1: environmental occurrence and behavior. Pathogens. 2015;4(2):256-68.

5 Kitajima M, Haramoto E, Phanuwan C, Katayama $\mathrm{H}$. Prevalence and genetic diversity of Aichi viruses in wastewater and river water in Japan. Appl Environ Microbiol. 2011; 77(6):2184-7.

6 Lodder WJ, Rutjes SA, Takumi K, de Roda Husman AM. Aichi virus in sewage and surface water, the Netherlands. Emerging Infect Dis. 2013;19(8):1222-30.

7 Alcalá A, Vizzi E, Rodríguez-Díaz J, Zambrano JL, Betancourt W, Liprandi F. Molecular detection and characterization of aichi viruses in sewage-polluted waters of Venezuela. Appl Environ Microbiol. 2010;76(12): 4113-5.

8 Cromeans T, Park GW, Costantini V, Lee D, Wang Q, Farkas T, et al. Comprehensive comparison of cultivable norovirus surrogates in response to different inactivation and disinfection treatments. Appl Environ Microbiol. 2014;80(18):5743-51.

9 Haramoto E, Kitajima M. Quantification and genotyping of Aichi virus 1 in water samples in the kathmandu valley, Nepal. Food Environ Virol. 2017;9:350-3.

10 Sdiri-Loulizi K, Hassine M, Aouni Z, Gharbi-Khelifi H, Sakly N, Chouchane S, et al. First molecular detection of Aichi virus in sewage and shellfish samples in the Monastir region of Tunisia. Arch Virol. 2010; 155(9):1509-13.

11 Di Martino B, Di Profio F, Ceci C, Di Felice E, Marsilio F. Molecular detection of Aichi virus in raw sewage in Italy. Arch Virol. 2013;158(9):2001-5.

12 Ibrahim C, Hammami S, Mejri S, Mehri I, Pothier P, Hassen A. Detection of Aichi virus genotype $\mathrm{B}$ in two lines of wastewater treatment processes. Microb Pathog. 2017; 109:305-12.

13 Onosi O, Upfold NS, Jukes MD, Luke GA, Knox C. The first molecular detection of Aichi virus 1 in raw sewage and mussels collected in South Africa. Food Environ Virol. 2019;11(1):96-100.
14 Burutarán L, Lizasoain A, García M, Tort LF, Colina R, Victoria M. Detection and molecular characterization of Aichivirus 1 in wastewater samples from uruguay. Food Environ Virol. 2016;8(1):13-7.

15 Bibby K, Viau E, Peccia J. Viral metagenome analysis to guide human pathogen monitoring in environmental samples. Lett Appl Microbiol. 2011;52(4):386-92.

16 Betancourt WQ, Kitajima M, Wing AD, Regnery J, Drewes JE, Pepper IL, et al. Assessment of virus removal by managed aquifer recharge at three full-scale operations. J Environ Sci Health A Tox Hazard Subst Environ Eng. 2014;49(14):1685-92.

17 Terio V, Bottaro M, Di Pinto A, Fusco G, Barresi T, Tantillo G, et al. Occurrence of Aichi virus in retail shellfish in Italy. Food Microbiol. 2018;74:120-4.

18 Le Guyader FS, Le Saux JC, Ambert-Balay K, Krol J, Serais O, Parnaudeau S, et al. Aichi virus, norovirus, astrovirus, enterovirus, and rotavirus involved in clinical cases from a French oyster-related gastroenteritis outbreak. J Clin Microbiol. 2008;46(12): 4011-7.

19 Hansman GS, Oka T, Li TC, Nishio O, Noda M, Takeda N. Detection of human enteric viruses in Japanese clams. J Food Prot. 2008;71(8): 1689-95. http://sfx.library.uu.nl/utrecht?sid=E MBASE\&issn=0362028X\&id=doi: \&atitle $=$ Det ection+of+human+enteric+viruses+in+Japan ese + clams \&stitle $=J .+$ Food + Protection \& title=Journal+of+.http://dx.doi.org/10.4315/ 0362-028x-71.8.1689.

20 Yamashita T, Kobayashi S, Sakae K, Nakata S, Chiba S, Ishihara Y, et al. Isolation of cytopathic small round viruses with BS-C-1 cells from patients with gastroenteritis. J Infect Dis. 1991;164(5):954-7.

21 Ngan PTK, Pattara K, Anh NT, Kanti DS, Tung PG, Shoko O, et al. Isolation and molecular characterization of aichi viruses from fecal specimens collected in Japan, Bangladesh, Thailand, and Vietnam. J Clin Microbiol. 2007;45:2287-8.

22 Yang S, Zhang W, Shen Q, Yang Z, Zhu J, Cui $\mathrm{L}$, et al. Aichi virus strains in children with gastroenteritis, China. Emerging Infect Dis. 2009;15(10):1703-5.

23 Thongprachum A, Takanashi S, Kalesaran AF, Okitsu S, Mizuguchi M, Hayakawa S, et al. Four-year study of viruses that cause diarrhea in Japanese pediatric outpatients. J Med Virol. 2015;87(7):1141-8.

24 Yamashita T, Sakae K, Kobayashi S, Ishihara Y, Miyake T, Mubina A, et al. Isolation of cytopathic small round virus (Aichi Virus) from pakistani children and japanese travelers from Southeast Asia. Microbiol Immunol. 1995;39(6):433-5.
25 Oh DY, Silva PA, Hauroeder B, Diedrich S, Cardoso DD, Schreier E. Molecular characterization of the first Aichi viruses isolated in Europe and in South America. Arch Virol. 2006;151(6):1199-206.

26 Kaikkonen S, Räsänen S, Rämet M, Vesikari T. Aichi virus infection in children with acute gastroenteritis in Finland. Epidemiol Infect. 2010;138(8):1166-71.

27 Reuter G, Boldizsár A, Papp G, Pankovics P. Detection of Aichi virus shedding in a child with enteric and extraintestinal symptoms in Hungary. Arch Virol. 2009;154(9):1529_ 32.

28 Jonsson N, Wahlström K, Svensson L, Serrander L, Lindberg AM. Aichi virus infection in elderly people in Sweden. Arch Virol. 2012;157(7):1365-9.

29 Drexler JF, Baumgarte S, de Souza Luna LK, Eschbach-Bludau M, Lukashev AN, Drosten C. Aichi virus shedding in high concentrations in patients with acute diarrhea. Emerging Infect Dis. 2011;17(8):1544-8.

30 Ouédraogo N, Kaplon J, Bonkoungou IJ, Traoré AS, Pothier P, Barro N, et al. Prevalence and genetic diversity of enteric viruses in children with diarrhea in Ouagadougou, Burkina Faso. PLoS One. 2016;11(4): e0153652.

31 Monastir C, Sdiri-loulizi K, Hassine M, Gharbi-khelifi H, Sakly N, Chouchane S, et al. Detection and genomic characterization of Aichi viruses in stool samples from detection and genomic characterization of Aichi viruses in stool samples from children in Monastir, Tunisia. J Clin Microbiol. 2009. 47:2275-8.

32 Ribes JM, Montava R, Téllez-Castillo CJ Fernández-Jiménez M, Buesa J. Seroprevalence of aichi virus in a spanish population from 2007 to 2008. Clin Vaccine Immunol. 2010;17(4):545-9.

33 Sdiri-Loulizi K, Hassine M, Bour JB, Ambert-Balay K, Mastouri M, Aho LS, et al. Aichi virus IgG seroprevalence in Tunisia parallels genomic detection and clinical presentation in children with gastroenteritis. Clin Vaccine Immunol. 2010;17(7):1111-6.

34 Sinclair RG, Choi CY, Riley MR, Gerba CP. Pathogen surveillance through monitoring of sewer systems. Adv Appl Microbiol. 2008; 65:249-69.

35 Kitajima M, Rachmadi AT, Iker BC, Haramoto E, Gerba CP. Temporal variations in genotype distribution of human sapoviruses and Aichi virus 1 in wastewater in Southern Arizona, United States. J Appl Microbiol. 2018;124(5):1324-32.

36 Altan E, Aiemjoy K, Phan TG, Deng X, Aragie $S$, Tadesse $Z$, et al. Enteric virome of Ethiopian children participating in a clean water intervention trial. PLoS One. 2018; 13(8):e0202054. 
37 World Health Organization. Guidelines for environmental surveillance of poliovirus circulation. Geneva, Switzerland. 2003. Available from: https://apps.who.int/iris/bitstream/ handle/10665/67854/WHO_VB_03.03_eng. pdf? sequence $=1$ \&isAllowed $=y$.

38 Lewis GD, Metcalf TG. Polyethylene glycol precipitation for recovery of pathogenic viruses, including hepatitis $\mathrm{A}$ virus and human rotavirus, from oyster, water, and sediment samples. Appl Environ Microbiol. 1988;54(8):1983-8.
39 Espinosa AC, Mazari-Hiriart M, Espinosa R, Maruri-Avidal L, Méndez E, Arias CF. Infectivity and genome persistence of rotavirus and astrovirus in groundwater and surface water. Water Res. 2008;42(10-11): 2618-28.

40 Kitajima M, Iker BC, Pepper IL, Gerba CP. Relative abundance and treatment reduction of viruses during wastewater treatment processes: identification of potential viral indicators. Sci Total Environ. 2014;488-489: 290-6.
41 Kitajima M, Rachmadi AT, Iker BC, Haramoto E, Pepper IL, Gerba CP. Occurrence and genetic diversity of human cosavirus in influent and effluent of wastewater treatment plants in Arizona, United States. Arch Virol. 2015;160(7):1775-9.

42 Ndiaye AK, Diop PA, Diop OM. Environmental surveillance of poliovirus and nonpolio enterovirus in urban sewage in Dakar, Senegal (2007-2013). Pan Afr Med J. 2014; 19:243. 